\title{
Assessment of The Rural Economic Structure of Güdül Town (Ankara) by Quantified Swot Analysis
}

\author{
Buse Şahin Dereyurt ${ }^{1}$, Elif Gündüz ${ }^{2} \odot$ \\ ${ }^{1}$ PhD. Arch. Stud., Faculty of Architecture, Department of City and Regional Planning, Gazi University, Turkey. \\ Email: busesahin1@gmail.com. \\ ${ }^{2}$ Associate Professor, Faculty of Architecture and Design, Department of City and Regional Planning, Konya Technical \\ University, Turkey. Email: egunduz@ktun.edu.tr. (Principal contact for editorial correspondence.)
}

\begin{abstract}
Purpose

Rather than solely having agricultural production at its core, rural development comprises of a multiaxial structure in which the socio-economic structure develops, non-agricultural economic diversification is assured, and a governance-based approached is adopted in the organization and participation mechanisms. The applicability and consistency of these intertwined axes entail an integrated approach to efforts in rural development. With the purpose of uncovering the critical points of the process, creating strategies intended for rural economic development within the axes valued by different stakeholders, and strengthening the participation mechanisms, SWOT Analysis, Analytic Hierarchy Process (AHP) integrated method, and TOWS matrix have been used to identify the Güdül rural economic development model.
\end{abstract}

Design/Methodology/Approach

In this study, the hierarchical structure established for the economic structure of Güdül is placed on the foundations of a SWOT analysis, quantified through Analytic Hierarchy Process, and evaluated within the framework of the three stakeholder's perceptions (local people, experts, and local governments) according to their priority values.

\section{Findings}

Thus, the extent of the respective effects of important factors in rural economic development has been identified. In conclusion, the decisive role of quantified methods in the identification of strategies and policies utilized in the process of Güdül's rural economic development has been manifested. Various strategies supporting the rural development and also institutions responsible for the implementation of these strategies were designated in light of the needs of Güdül and the expectations of the local people living in rural areas.

\section{Research Limitations/Implications}

The version of the questionnaire forms compatible with the SWOT-AHP technique, the scarcity of local manager surveys, the lack of answers to the questions of the local people are among the main difficulties encountered.

\section{Originality/Value}

This study is quite original in that it is the first strategic rural development plan model made specifically for Güdül, related to the participation of indigenous people in planning initiatives and transparently reflects the sometimes combined and sometimes changing views of local people, experts and local administrators about the importance of SWOT groups has a quality. 


\section{INTRODUCTION}

The concept of the rural area that has been recognized as the opposite of the urban and explained through conventional theories and approaches shows, indeed, a great variety in accordance with its history, traditions and potential. There is not an agreed upon and universal approach used to define the rural area (Nijkamp, Baycan, \& Gulumser Akgun, 2006).

Changes in social and political conditions, diversity in global and economic policies make the boundaries of cities and rural areas increasingly uncertain. This uncertainty brings new planning tools for rural and urban areas into the agenda, and many countries continue to seek planning specific to their own structure (Champion and Hugo, 2004).

Frequently referred to as "village development," rural development includes organization mechanisms and multifaceted processes in which local inhabitants are directly affected. Problems pertaining to rural development are approached from various aspects (physical, socioeconomic, political etc.) in consideration of the long-term support and the benefits to public (Geray, 2011). Although the conceptual framework for the rural is known to stand opposite of the "urban," the fact that this opposition is losing its validity with the influence of global factors, that the majority of the world population struggles to exist in urban areas for various reasons, and the already nebulous boundaries between the rural and the urban are further blurred necessitates constant rethinking of the concept of rural (Tekeli, 2016).

Compared to urban areas, rural areas are small-scale settlements in terms of density, area, and capacity, which leads to numerous problems with regards to governance as well. Various definitions have appeared due to changing rural textures, and the transformation in the structure and the texture the rural areas has enriched these definitions (Özkan, 2007). Rural areas cannot be defined with a generalized point of view (Baycan Levent, Gülümser, \& Nijkamp, 2010) due to several factors such as population and density, socio-economic and demographic structure, and idiosyncratic characteristics that distinguish rural from urban areas (Ilbery, 1998).

Besides exhausting their resources, rural areas, dominated by a production-based structure, have also started being dependent on urban areas under the inevitable influence of the globalization process. As part of the negative effects of globalization, the consuming society has caused an upsurge in the service industry in rural areas and relegation of agricultural production to the level of a hobby practice (Tekeli, 2016).

Changing and flourishing industrial structure leads to a diversification of the rural economy, which entails a transformation in the socio-spatial structure. Unique to a region in the relationship between the global and the local, rural texture proves to be an important tool in regaining the former attraction of rural areas by focusing the attention on rural industry, tourism and service industry. (Epstein and Jezeph, 2001; Costis, 2003; Davoudi and Stead, 2003; Yenigül, 2017). 
The complex structure brought about by the authenticity of rural areas and non-holistic planning approaches makes the managing of the development process even more difficult. SWOT analyses including different points of view enable the identification of the current situation of a rural area in a transparent and fair way as well as helping reveal the expectations from the area. By hierarchically organizing the quantitative and qualitative values that are hard to quantify, AHP, in this respect, significantly contributes to the analyses of the present situation that would lead the development process. (Rovai \& Andreoli, 2018).

Rural development is defined on three intertwined axes. The first one is encapsulating a broad framework including the inhabitants of rural areas and the vitality of rural spaces. Second one is working in line with the physical, socio-economic, and environmental sustainability goals. Finally, the last one is achieving social welfare on the basis of sustainable rural development (Moseley, 2012). At this point, besides ensuring agricultural productivity for the rural economy to gain competitive power in fast changing markets, several participation-based approaches were developed to sustain the living conditions of rural populations. These approaches identified the local distinguishing characteristics and aimed to preserve the natural and cultural assets of rural areas. Especially queries such as "localization, empowering local populations on site, and participation of all stakeholders in development processes" have contributed to the approaches to rural development (Gülçubuk, 2015).

Rural development studies inquire answers to questions such as "Who is the target population?"; "Who will execute?"; "What will be done and how will it be concluded?"; "What is the measure of success?"; and "How will it be rendered sustainable?" Assessment of rural areas as a potential resource with economic value is further strengthened by the globally widespread concept of "sustainability." Sustainability of rural areas is possible only when the inhabitants of such areas embrace the natural and cultural living spaces; feel a sense of belonging to these areas; cultivate the soil in an informed, productive, and effective way; participate in the production; earn a satisfactory income; and use the income to enhance their standards of living. Utilization of social, cultural, and natural resources in rural areas will provide a significant economic power for our country. In order to assure this, sound policies that depart from correct areas and aim at accurate target populations should be devised.

The applicability and consistency of these intertwined axes entail an integrated approach to efforts in rural development. Depleting resources, diversifying and transforming settlement design patterns, and the everwidening gap between income groups bring about a non-homogeneous distribution and a fast impoverishing rural society. In order to find solutions for the problems of settlement design patterns and to define a holistic development process, the current situation necessitates changes in rural economy policies that enable a fair and balanced use of resources. Güdül, a town $90 \mathrm{~km}$ away from the capital Ankara, has been facing problems such as a fast decrease in its population, diminished interest in 
agricultural activities, heavy migration to the metropolitan area, wasteful consumption of environmental resources and the failure in eliminating regional inequalities. Neighboring towns Ayaş, Beypazarı, Çamlıdere, and Kizılcahamam successfully turned their natural and cultural resources into economic opportunities and made significant progress in rural development as opposed to Güdül. This study aims to present some information about the potential of the town and its physical, social, economic and administrative structure, and to identify the internal (strengths and weakness) and external (opportunities and threats) factors of assessment. Also, the following objectives have been set:

- $\quad$ Creating development strategies that could interpret the entire settlement area by using environmental, socio-economic and physical data.

- $\quad$ Presenting a model of a sustainable and holistic strategic rural development plan intended to serve as a guideline and a foundation for spatial plans.

This study explores how to benefit from the potential of rural areas by effective utilization of resources, how to evaluate the compatibility of the economic diversification with the socio-cultural and traditional structure of the local people, and how to make planning in line with this local texture. Within this framework, general information about the economic structure of the town is presented first and then the potential is evaluated. These assessments are based on the data acquired from stakeholders (local people, experts, and administrators) through qualitative and quantitative methods. SWOT analysis of the town's economic structure is prepared in light of the information obtained from these personal interviews. A model proposal has been developed consisting of SWOT analysis groups (strengths, weaknesses, opportunities, and threats) and SWOT factors. Findings are assessed in a comparative framework by using the Analytic Hierarchy Method, a multicriteria assessment approach, and taking into consideration the factors regarding the town's natural, historical, and cultural policies as well as the goals on land-use. Weighted scores for the most appropriate economic activities that can be carried out in town are determined, and then the priority scores of the activities that got the highest weighted scores are calculated. Departing from the results of the analyses, alternative strategies are developed that will enable the effective utilization of resources for the economic amelioration of Güdül; identification of the attitudes, power, and expectations of all stakeholders; and placing these factors at the center of planning. Thus, this study aims at putting forward the most appropriate planning decisions.

This study identifies the priority values of the factors involved in the strengths, weaknesses, opportunities, and threats regarding the research area simultaneously and comparatively in terms of economics, and attributes particular importance to the actors and their participation while ascribing to these qualitative factors a dynamic, analytical, and 
Assessment of The Rural Economic Structure of Güdül Town (Ankara) by Quantified Swot Analysis

rational dimension. In this regard, the study is considered to be important with regard to its approach that permeates the whole process from decision-making to the identification of objectives and strategies, and through the implementation process.

\section{CASE STUDY AREA}

\section{Research Findings}

A transparent and participatory, open source, empirical, organizational and strategic approach was adopted in line with the research objectives. Primarily, a letter of intent was written in order to inform the decisionmaking mechanisms of Güdül about the research, which was followed by preliminary meetings. These meetings started with the mayor, as the representative of the local people, and the district governor, as the representative of the state. The said institutions played an active role in communicating with the local people.

In order to reach out to all the actors and stakeholders expected to participate in the process, an informational meeting was organized at the town center that included interactive and feedback-based workshops for women, men, and young adults. An invitation to this meeting was prepared and posted in the busiest parts of the town in addition to regular public announcements made by the municipal personnel.

Only 12 people participated in this meeting, including the municipal personnel and some of the notable figures of town. The past and the future of Güdül were discussed with the participants of the meeting and the primary needs of the town were identified. Also, through an exchange of ideas focusing on the expectations, suggestions, demands, the strengths, weaknesses, opportunities, and threats regarding Güdül were set forth, which culminated in the final version of the SWOT analysis. At the end of the meeting, a series of fruitful interviews were also conducted with the local shopkeepers of Güdül who could not attend the meeting. A survey was implemented among the local people, experts, and local administrators, who are important actors in the executive branch during the process of strategic rural economic development. The problems in the area and relevant important points were laid bare in a participatory and transparent approach, and a series of interviews were conducted with the local people, experts, and local administrators with the purpose of identifying the characteristics of the town that determine the economic strategies. The future of Güdül and the status the town is expected to reach were paid particular attention in the interviews.

\section{General Characteristics}

Güdül is a town $90 \mathrm{~km}$ away from Ankara. Its neighboring towns are Ayaş, Beypazarı, Çamlıdere, and Kızılcahamam. Although it is located within the greater Ankara metropolitan area, Güdül tries to maintain its rural characteristics. Güdül, which strives to protect its rural characteristics despite being under the influence of Ankara metropolitan municipality, distinguishes itself from neighboring towns and municipalities with its 
high potential for rural development, efforts to preserve its rural characteristics, and administrative ties with Ankara, the capital of Turkey. The economy of the town that is primarily based on agricultural production has dramatically narrowed due to lack of developments in other sectors. This shrinkage in economy caused a regression in the socio-economic level of development and an increase in the rates of unemployment and migration to other towns and cities.

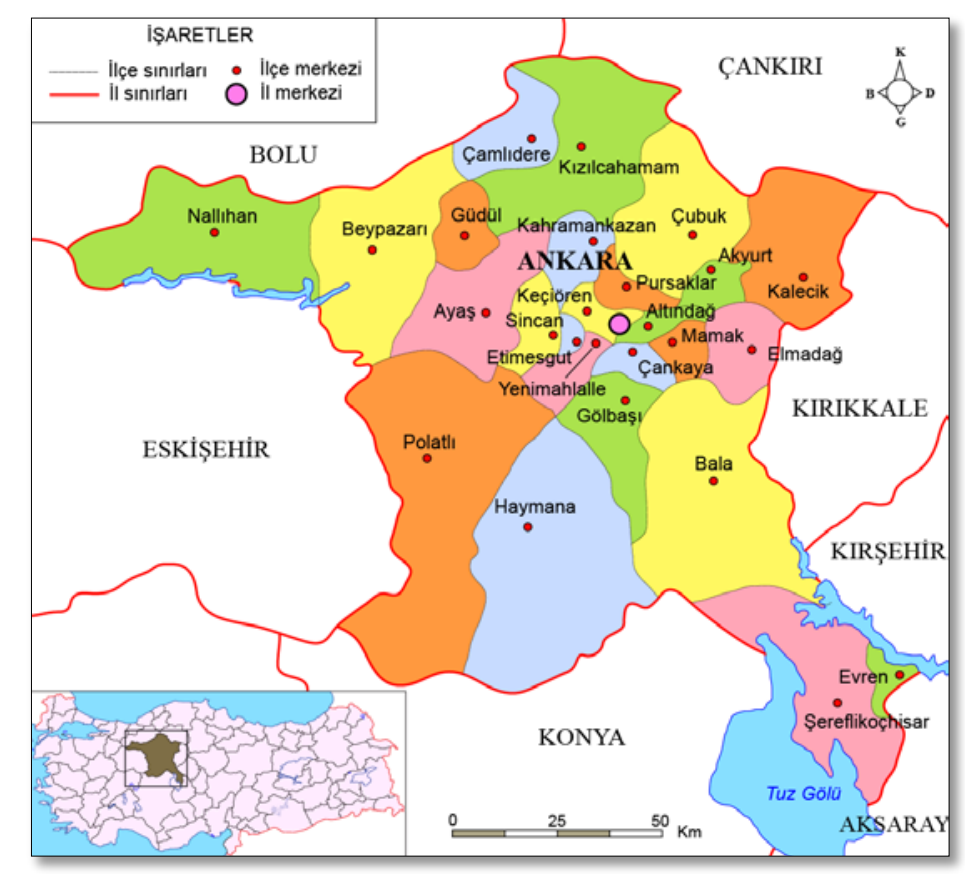

The number of neighborhoods in Güdül, which strives to preserve its particular characteristics and to sustain agricultural production, rose from 4 to 31 after the town joined Ankara Metropolitan Municipality in 2014. For this reason, maintaining rural characteristics has become further difficult for Güdül that has also acquired urban traits. Integrating the advantages of urbanness and the existing potential of the rural that has yet to be used is of utmost importance for achieving the targeted level of rural development (Anonymous, 2017).

Güdül, located in the northwest of Ankara, has hosted several civilizations since prehistoric times up until today. Kirmir Stream, a branch of the Sakarya River, Suvari Stream and İlhan Stream flow through the mountainous town and irrigate agricultural lands. The town has a humid micro-climate due to the Kirmir Valley situated in the north.

In Güdül, located $90 \mathrm{~km}$ from Ankara city center, the only transportation is by road. When the characteristics of transportation and technical infrastructure of the town were examined, transportation connections and the diversity both within and outside of town were found to be inadequate.

The fact that Güdül does not have enough public places and community centers despite its rich historical heritage and cultural and natural values considerably restricts the development of a social structure. A teacher's
Figure 1. Ankara district border map (Anonymous, 2017). 
Assessment of The Rural Economic Structure of Güdül Town (Ankara) by Quantified Swot Analysis

lodge, a public education center, a social service and education center for women, and a dormitory are located at the town center. With a total of 31 neighborhoods, Güdül is home to 10074 people according to the 2018 Census. Women comprise 51\% (5095) and men 49\% (4979) of the total population. (Anonymous, 2017).

\section{Economic Structure}

Although the economy of Güdül is suitable for rural economic development in terms of the town's geographical location, the economy is focused more on agriculture. The slowing down in the agricultural sector and the fast decrease in agricultural production in the post-1980 period in Ankara negatively affected the agricultural infrastructure of Güdül. A consumption, rather than production-oriented structure started taking shape, thus making it difficult to transform the rich agricultural potential into added value and an economic resource for the town. As opposed to cities that provide economic diversification, regressing agricultural production caused rural areas to be impoverished and made immigration a necessity for the local people. Currently, Angora goat husbandry and agricultural and animal products are the main pillars of Güdül's economy (Anonymous, 2019a).

The low production potential in the fields suitable for agriculture is among the factors that restrain agricultural production. Dry farming is done because of the effects of plateaus, and also irrigated farming is done on the irrigable parts of the valleys. In terms of land distribution, $66 \%$ of a 46737-ha-area is suitable for farming. Forests constitute the $16 \%$, unused land $1.5 \%$, and non-agricultural land $0.5 \%$ of the remaining area. The major crops in Güdül are wheat, barley, vetch, sunflower, corn, and tomato (Anonymous, 2019b).

Of the 20822-ha agricultural land, fields cover an area of 17780 ha, vegetable gardens 1090 ha, vineries 1500 ha, and fruit orchards 452 ha. In recent years, viticulture activities have gained importance at the town center and in adjacent neighborhoods, making Güdül a center for the production of the highest-grade table grapes. Of the 30478-ha agricultural land, the irrigable parts occupy an area of 2131-ha. 70\% of irrigation is conducted by the local people and the remaining $30 \%$ by the State Hydraulic Works (ponds, dams, irrigation canals, and systems established by agricultural cooperatives) (Anonymous, 2019b). Fresh fruits and vegetables grown in the area are sent to Ankara for sale. Also, activities of cherry production and viticulture are supported for improvement (Kaplan, 2007).

Husbandry is one of the main sources of income of the local people. Registered pasture and forage areas cover an area of 7459 ha, and forages are mostly located to the east of Güdül town center. Local people have started having difficulties with grazing after the incorporation of forages in forest areas, and the number of animals is also gradually decreasing. Besides cattle (551 businesses) and small cattle (219 businesses) 
husbandry, apiculture, fishery, and poultry farming are common in the area.

Although the entirety of the area is suitable for apiculture, it is commonly practiced only in the northern parts of the town. With its low costs and high economic yields, apiculture is one of the most profitable sectors in Güdül. However, local beekeepers complain about the racial hybridization in bee colonies provided as part of state incentives (Anonymous, 2017).

Kirmir Stream in the area has potential for fishery with its populations of carp, sheatfish, and local freshwater fish. However, the three dams built on Kirmir polluted the water, thus damaging the fisheries (Anonymous, 2017).

Detached houses with yards are common in Güdül, and most households raise poultry in their yards. On the one hand, amateur poultry farmers sell their products in local markets as a way to earn an additional income. On the other hand, there are two households who are professional poultry farmers and these businesses receive state support. One of the chicken farms is located in Garipçe Neighborhood while the other one is on Beypazarı road. Both farms operate with a capacity of 50000 (Anonymous, 2017).

Although cattle farming is done primarily in Garipçe, Karacaören, Çağ and Güneyce neighborhoods, there's a significant decrease in recent years due several factors that negatively affect husbandry. For example, the area of grazing land has significantly decreased when pastures were turned into forests. Secondly, after the enactment of the law that turned village settlements into neighborhoods of the metropolitan, local people who had barns adjacent to their houses received complaints from their neighbors due to the foul smell and noise coming from the barns. Barns, thus, had to be moved away from residential areas, which increased costs. Thirdly, a necessity to purchase hay and fodder arose because of the decreasing production. Also, the drop in profit rates and lack of employment areas led the young population to immigrate to the city, which negatively affected husbandry (Anonymous, 2017).

Angora goat holds a significant place in small cattle farming, and angora wool is known to have brought a substantial revenue to the region's and the country's economy in the past. However, fiber and imported leather, the products of mechanization in recent years, brought about a dramatic decrease in the production of angora wool on account of low costs and sufficient functionality. Diminishing demands parallel to the decrease in population also caused a decline in production. Thus, Güdül has lost the importance it previously attached to the production of angora wool (Anonymous, 2017). Güdül Angora Wool and Fleece Agricultural Sales Cooperative supports the production in the town (Kaplan, 2007).

Although the location of the town on a branch of the Silk Road was a pioneering factor in commercial activities, heavy immigration out of Güdül decreased the production rates and commercial activities. Angora wool and leather factories had production of shoes and especially "mest" 
Assessment of The Rural Economic Structure of Güdül Town (Ankara) by Quantified Swot Analysis

shoes (a kind of soft footwear) in the past, but the production cannot keep pace with today's competitive environment and is facing extinction. Instead of selling their own products, existing factories sell products purchased from places like Beypazarı and Konya due to lower costs. It is also known that there is a great number people from Güdül who are engaged in trade in Ankara, especially in Ulus region (Kaplan, 2007).

There are not any specialized or organized and large-scale industrial zones within the borders of Güdül. Such an industrial zone focusing on leather production with the purpose of using the existing potential in town was considered in the past; however, this tentative plan was never realized nor put on agenda again due to the gradual decline in husbandry. The decrease in population in recent years stands as the biggest obstacle in front of the possibility of opening a new industrial zone and creating an employment potential. Commercial activities currently continue in small-scale industrial zones and factories (Anonymous, 2017).

The number of roasted chickpea and leather factories, which became symbols of Güdül in the past, has significantly dropped as well. About 20 years ago, there were 50 factories producing roasted chickpeas and 35 shops producing leather. Today we can find only 1 manufacturer of roasted chickpeas (İsmail-Cengiz Altındağ Brothers) and 2 leather factories. The growth in the production of roasted chickpeas due to mechanization has restricted traditional production by causing a decrease in production costs on a company basis.

The production of roasted chickpeas stayed alive for a while for the sake of preserving the tradition, but it also eventually lost its attraction. The drop in sales rate dragged the manufacturers of roasted chickpeas into an economic distress. Also, manufacturers are having trouble finding people to train because of youth migration. A project has been launched in order to revive this former symbol of Güdül. Accordingly, a Street of Roasted Chickpea Manufacturers is designed in a protected urban area with adjacent one-floor stores with wooden fronts. The objective of this project, carried out in collaboration with Güdül Municipality and Güdül District Governorship, is to ascribe a new function to simple but authentic and traditional wooden fronts (Anonymous, 2017; Kaplan, 2007).

Knife-making, a sector in Güdül dating back to 5 years ago, offers diversification in the economy of the town. Besides being a product of hard labor and great efforts, knives made in Güdül also reflect our cultural past. The motifs and designs used in the Ottoman Empire are today meticulously carved on knives and presented to the aficionado. The production takes place in one store (Erdal Atasoy) and sale in three stores, one of which also offers online sale options. This local craft is promoted in fairs at specific times of year. People living in Turkey who are also interested in the craft of knife-making visit the town of Güdül to see and purchase these knives (Anonymous, 2017).

Unemployment proves to be an important problem for Güdül. The young people of Güdül try to find employment in neighboring cities, Ankara being in the first place, due to the inadequacy of work areas and 
employment opportunities in town. Despite the efforts to keep them alive, economic sectors such husbandry, production of roasted chickpeas, and the leather trade do not yield expected profits and are interrupted by various factors, which is among the major causes of unemployment. New and diverse fields of employment are needed in order to revitalize the economy. A number of factors show Güdül's suitability to host new areas of employment. First of all, it is located close to the capital of Turkey, Ankara, a physical, social, and governmental point of connection. Also, the town still maintains its rural characteristics and possesses the potential to create diversity in rural economy thanks to rural values. Considering its history, geography and fertile lands, the scarcity of employment constitutes a significant problem (Anonymous, 2017).

\section{DATA AND METHOD}

\section{Data}

Surveys conducted with the local people of Güdül, local administrators, and experts constitute the main data source of this research.

Local people are those who have an established and permanent settlement largely in Güdül. They reside in Güdül, use the town's resources, and contribute to town's economy. In brief, locals are people who experience Güdül the most and who are most likely to be affected by the administrative decisions.

Experts are the people who are directly or indirectly engaged in the guidance and development of Güdül's rural development plans, and also technical staff working in institutions such as Güdül Agricultural Directorate, Güdül Forest Directorate, Güdül District Governorship, and Güdül Municipality.

Local administrators include the administrative staff working in local government units and managements (municipality, district governorship, local heads of neighborhoods, organizations etc.) in the town of Güdül.

While defining the physical, social, economic, and governmental structure of the study site, we utilized;

- The analyses conducted by Ankara Metropolitan Municipality and Güdül Municipality regarding the site, and Google Earth satellite images for maps and plans,

- $\quad$ Microsoft Excel for data digitization and analyses;

- $\quad$ Adobe Photoshop (CC) for the production of thematic maps and visuals;

- $\quad$ Research Report on Town of Güdül (2017), Güdül District Governorship (2019), and Güdül Municipality (2019) for institutional reports and data;

- And lastly observations made and photographs taken in the study site. 
Assessment of The Rural Economic Structure of Güdül Town (Ankara) by Quantified Swot Analysis

\section{Method}

Saaty and Vargas (2001) stated that the Analytic Hierarchy Process (AHP), first put forward by Myers and Alpert in 1968, allows for the assessment of both quantitative and qualitative factors. Kurtilla et al. (2000) delineated the general framework in the strategic decisionmaking process by SWOT analysis, and added that AHP confers a rational, analytical, and quantitative aspect to this qualitative framework. Lee et al. (2006) combined the balanced scorecard approach with a fuzzy AHP method in performance assessment. Kangas et al. (2003) used this method with the purpose of identifying the protection strategies in forests, which are sensitive ecosystems. In a similar manner, Masozera et al. (2004) evaluated the impact of local communities in the Forest Protection area, the institution of the state, and environmental groups on plans or strategies in a community-based governance model. This method was used by Cengiz \& Çelem (2005) (in the strategy-making process in rural areas; by Çelik \& Murat (2008) in the assessment of city of Bartın's economic structure; by Akbulak (2016) and Yılmaz \& Zorlu (2018) in the strategy-development process regarding the tourism activities in rural areas.

This study aims at assessing the economic activities and demands that are planned as part of rural development plans in Güdül and identifying the proper planning strategies. The most suitable strategy is determined by the Analytic Hierarchy Process (AHP) method.

The flowchart of the research is presented in Figure 2:

In this study, stakeholders are subsumed under three groups as local people, experts, and local administrators. Local people are those who have an established, permanent settlement largely in Güdül. They reside in Güdül, use the town's resources, and contribute to town's economy. In brief, locals are people who experience Güdül the most and who are most likely to be affected by the administrative decisions. Experts are people who are directly or indirectly engaged in the guidance and development of Güdül's rural development plans, and also technical staff working in institutions such as Güdül Agricultural Directorate, Güdül Forest Directorate, Güdül District Governorship, and Güdül Municipality. Local administrators include the administrative staff working in local government units and managements (municipality, district governorship, local heads of neighborhoods, organizations etc.) in the town of Güdül.

In the design process of the survey, in addition to observations as part of the field work, informal face-to-face meetings with the local people, interviews with the experts holding positions or doing research in the region, and meetings with the local administrators who were integral to local development activities were held. Furthermore, surveys that were implemented in similar studies using the SWOT-AHP integrated method were consulted. The feedback received from different interaction groups who experience and endeavor to maintain the local texture not only 
shaped the survey in such a way as to test the pulse of the local, but also brought an authenticity to the survey.

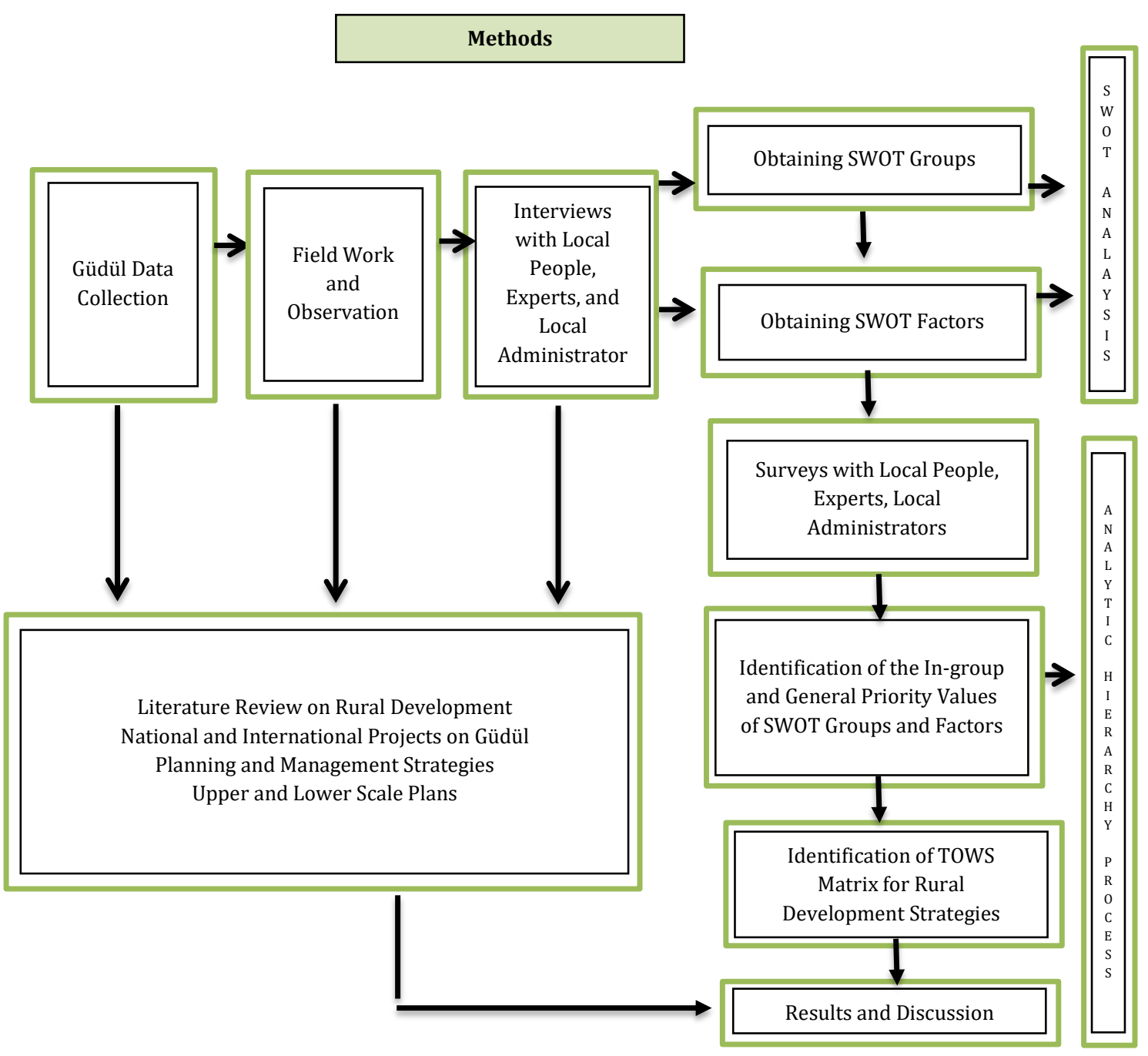

During the organization of these surveys in terms of content and scope, national and international literature on the subject was reviewed, the work of Güdül urban craft workshops was resorted to, and the experts were consulted. In accordance with the expert opinion, the options that were deemed to be unnecessary and low in measuring power were eliminated from the first draft of the survey. Pilot studies were conducted with local shopkeepers with the aim of doing a pre-assessment of the survey questions and evaluating the perception of stakeholder groups. Items that were found to be confusing and hard to understand were removed from the surveys.

The survey was conducted at Güdül town center. Various difficulties were encountered in the application of survey forms in line with the combined SWOT-AHP method. Among the major problems are the scarcity of the response from local administrators due to their desire to be impartial and the unwillingness of local people to give valid answers due to finding the survey questions too long or unintelligible. 
In order to assure the efficacy of the local participation mechanisms, in depth face-to-face and over-the-phone surveys were conducted with the above-mentioned stakeholders (local people, experts, and local administrators) regarding the current situation. As a result of these surveys, strengths, weakness, opportunities, and threats with regards to the town of Güdül were identified through a participatory approach, and a SWOT analysis was prepared that takes into consideration the economic factors in rural development.

Two types of surveys were prepared to be delivered to three groups of stakeholders who are also decision-makers. One of these surveys targets local people and the other one is for experts and local administrators. During the organization of these surveys in terms of content and scope, National and international literature on the subject was reviewed, the work of Güdül urban craft workshops was resorted to, and the experts were consulted. In accordance with the expert opinion, survey forms were created that included the assessment of factors in relation to one another and the identification of the priority values (1-9 scale). These surveys proved to be quite useful in the creation of weighted SWOT factors and identification of priority values. Pilot studies were conducted with local shopkeepers with the aim of doing a pre-assessment of the survey questions and evaluating the perception of stakeholder groups. Items that were found to be confusing and hard to understand were removed from the surveys.

In this study, while taking into consideration the preferences of stakeholders, an integrated SWOT-AHP approach is used in the designation of the strategies to identify the most suitable economic activity essential for rural development in town and in ranking these strategies in order of importance. The objective of the SWOT analysis, which is considered to be a tool of analysis and planning, is to approach the current situation from multiple perspectives and to set a course of action for future use. There are several studies combining SWOT analysis and the AHP method in various fields such as economy, energy policies, resource management, healthcare, architecture, engineering, and tourism. The relative importance of the factors identified through AHP and the importance of groups these factors belong to are designated, and effective solution suggestions are generated within the framework of a multi-criteria decision-making process. Decision-makers identify the factors and the relative priority value of each factor in their group within the framework of the hierarchical structure that is established on the identified axes. Then they score the factors within the scope of the values and definitions presented in Table 1 . This scoring results in a matrix of paired comparison. As a result of the eigenvalue and eigenvector calculations on this matrix, the weight of the SWOT group and factors are calculated (Akbulak, 2016). 
Table 1. AHP rating scale (Saaty, 2008)

\begin{tabular}{|c|c|c|}
\hline Numerical Scales & $\begin{array}{l}\text { Description of } \\
\text { Importance }\end{array}$ & Explanation \\
\hline 1 & equal importance & $\begin{array}{r}\text { two factors equally contribute } \\
\text { to one objective }\end{array}$ \\
\hline 3 & $\begin{array}{l}\text { moderate } \\
\text { importance of one } \\
\text { factor over } \\
\text { another }\end{array}$ & $\begin{array}{r}\text { experience and personal } \\
\text { appreciation slightly favor one } \\
\text { factor over another }\end{array}$ \\
\hline 5 & $\begin{array}{l}\text { strong } \\
\text { importance of one } \\
\text { factor over } \\
\text { another }\end{array}$ & $\begin{array}{r}\text { experience and personal } \\
\text { appreciation highly favor one } \\
\text { factor over another }\end{array}$ \\
\hline 7 & $\begin{array}{l}\text { very strong or } \\
\text { demonstrated } \\
\text { importance }\end{array}$ & $\begin{array}{r}\text { one factor is strongly favored } \\
\text { and its dominance is supported } \\
\text { in practice }\end{array}$ \\
\hline 9 & $\begin{array}{l}\text { extreme } \\
\text { importance }\end{array}$ & $\begin{array}{l}\text { evidence favoring one factor } \\
\text { over another is of the highest } \\
\text { possible order of affirmation }\end{array}$ \\
\hline $2,4,6,8$ & $\begin{array}{l}\text { intermediate } \\
\text { values between } \\
\text { two scales }\end{array}$ & when a compromise is required \\
\hline
\end{tabular}

First, the weight scores of SWOT groups and factors were determined by taking into consideration the economic aspects of rural development and with the aid of the AHP method explained above. Then the general weight score of SWOT factors is calculated by multiplying the score of each SWOT factor with the weight score of the SWOT group to which the factor belongs. The general weight scores of all SWOT factors were thus obtained and, as a result, qualitative SWOT factors were quantified through the method of AHP.

Identification of economic development strategies: At this stage of the study, strategies oriented towards assuring the economic development in Güdül were determined. While the general weights of SWOT factors were taken into account in the identification of strategies, other objectives included bolstering the already strong aspects of Güdül's economy, eliminating its weaknesses and threats, and making use of the opportunities.

Local people, who live in the region and are directly affected by the strategies, determine the priority values of the strategies that would support the development in the application of the integrated model of SWOT-AHP. Thus, participation and incentivization mechanisms involved in the rural economic development plans will be improved while transparent and fair participation mechanisms will be devised for disadvantaged groups. In addition to the direct participation of local people in the process, an economic development that aligns with the characteristic structure of the region and that supports rural economic diversity will be ensured in accordance with the objective of satisfying the primary needs of people and enhancing the quality of life. 
Assessment of The Rural Economic Structure of Güdül Town (Ankara) by Quantified Swot Analysis

Incorporation of local people's immediate needs in the policies and implementations that are generated within the framework of rural economic development also supports the direct participation of people in this process.

\section{FINDINGS}

The size of the sample population for surveys was determined. Where population size is 10,000 and more, the following formulations were used to determine the sample size (Aksoy \& Elmacl, 2009).

Table 2. Sample area size determination (Aksoy \& Elmacl, 2009)

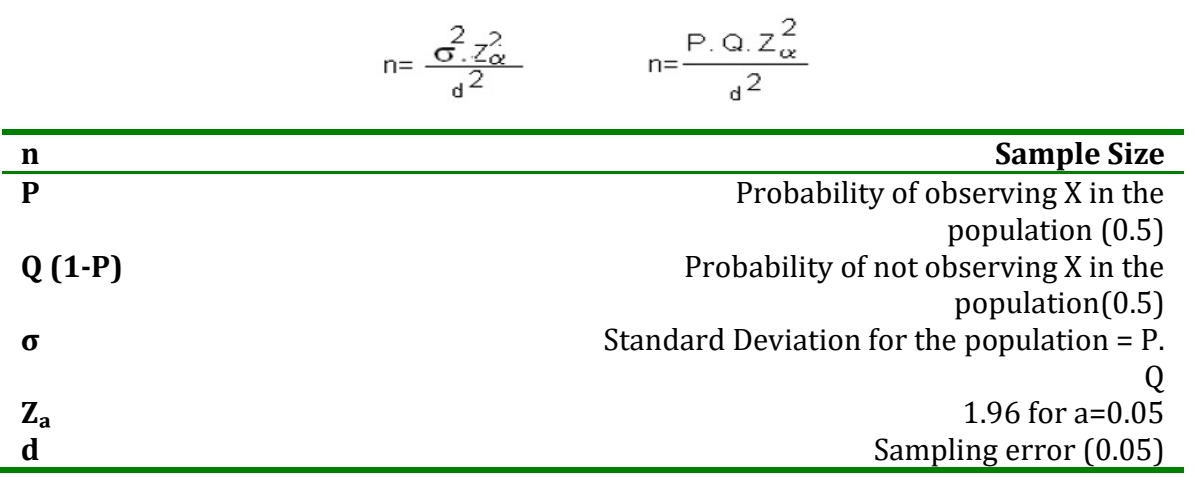

At $\alpha=0.05$, in Güdül where the population size (N) is 10,074 with an \pm 0.05 sampling error, area sampling size of the questionnaire to be delivered to the local people is determined to be 38, without the margin of error. When the margin of error is also included, the necessary number of questionnaires is estimated to be at least 40 . Within the study site, 35,12 , and 3 questionnaires were administered to local people, experts, and local administrators, respectively. The purpose of the questionnaires is to reveal Güdül's current potential and expectations in an objective, transparent, and fair manner. To that end, a homogenous distribution of Güdül's general frame was intended to be achieved in the questionnaires with regards to factors such as age, gender, economic status, and education (Table 2).

A number of factors received special attention in the delivery of surveys. It was made sure that the targeted local people were adults living within the town boundaries of Güdül. Secondly, experts were selected from a variety of different professions such as state officials, accountants, city planners, architects, sociologists, economists, and engineers and so forth (Table 3). Lastly, district governorship staff and the local head of the neighborhood were given the surveys in person-person.

Table 3. Güdül expert surveys professional group and number of surveys applied

\begin{tabular}{ccc}
\hline Occupational Group & Number of Surveys & $\mathbf{\%}$ \\
\hline Technician & 2 & 16,66 \\
Civil Servant & 3 & 25 \\
Accountant & 2 & 16,66 \\
\hline
\end{tabular}




\begin{tabular}{ccc} 
City Planner & 1 & 8,33 \\
Architect & 1 & 8,33 \\
Sociologist & 1 & 8,33 \\
Economist & 1 & 8,33 \\
Engineer & 1 & 8,33 \\
Total & 12 & 100 \\
\hline
\end{tabular}

According to the Economic SWOT analysis of the town of Güdül, a total of 29 factors were identified: 8 factors in the strengths group, 9 in the weaknesses group, 4 in the opportunities group, and lastly 8 in the threats group (Table 4).

Table 4. Güdül economic SWOT analysis from (Sahin \& Gündüz, 2018) prepared by compiling

\begin{tabular}{l} 
Economic Strengths (ES) \\
\hline ES1- Local people's main sources of \\
income are agriculture and animal \\
husbandry \\
ES2- Geothermal resource potential can \\
be utilized in agriculture and tourism \\
ES3- Trade and recreational activities in \\
the region are revived due to the \\
waterfront arrangement along Kirmir \\
Stream \\
ES4- Geographical structure is suitable \\
for the launching of new employment \\
areas \\
ES5- Angora wool trade occupies a \\
significant place in the traditional \\
structure \\
ES6- Local people are occupied with \\
apiculture, fishing, and poultry farming \\
ES7- Amateur poultry farmers \\
contribute to economy by selling their \\
products in local markets and mobile \\
sales stands \\
ES8- Recreational activities are \\
introduced on a designated street to \\
revive the traditional manufacturing \\
techniques of roasted chickpeas
\end{tabular}

\section{Economic Opportunities (E0)}

E01- Angora goat is native to Ankara

E02- Angora wool significantly contributes to the national and regional economy

E03- Roasted chickpea, an important product of the region, has branding potential

E04- The town has potential in various fields to get a foothold in domestic and foreign markets

E05-Viticulture activities are improving and gaining importance

E06-Kirmir Stream is suitable for fishing activities

E07- People visit Güdül to see and purchase the knives made in town

EW1-Seed amelioration efforts are
insufficient
EW2-Cattle farming is in decline

EW3-Households with low number of animals are incurring higher costs for animal care and their profits rates are decreasing

EW4-The number of unemployed people is on the rise and there are not adequate fields to provide employment for these people

EW5-The town does not own a developed industry sector

EW6-Production of hay and fodder required for animal husbandry is not sufficient

EW7-There are no food safety efforts and studies

EW8-Cooperativization infrastructure is insufficient

EW9-Infrastructure for competitiveness and branding is insufficient

\section{Economic Threats (ET)}

ET1- The production of angora wool, which indeed has high economic return on the national and regional levels, has significantly dropped

ET2- The number of roasted chickpea and leather factories, which became symbols of Güdül in the past, has significantly dropped

ET3-Touristic areas with high branding value cannot be integrated with Güdül

ET4- Natural resources in rural residential areas cannot be integrated into tourism and the investments in agritourism are insufficient

ET5- Although Ankara lies at the center of Turkey and the Middle East in the health sector, this potential cannot be integrated with the tourism sector 
ET6- The importance of the utilization and accruement of agriculture-based capital has been lost due to town's proximity to Ankara

ET7- Businesses have insufficient institutional capacity for branding and foreign trade

ET8- Tourism sector cannot make a significant contribution to economy due to the shortage in accommodation facilities in the area

Weighted scores of the economic SWOT group and SWOT factors were assigned using the AHP method and in consideration of the factors that impact the improvement of the economic structure. The scores of the economic SWOT group and SWOT factors were primarily identified, and then the general weight score of each factor was calculated. Then the economic SWOT groups, scored by the local people, experts, and local administrators, are analyzed from the viewpoint of the three stakeholders (Table 5):

Table 5. Weightiness of economic SWOT factors

\begin{tabular}{|c|c|c|c|c|c|c|c|c|c|c|}
\hline \multirow{2}{*}{$\begin{array}{l}\text { SWOT } \\
\text { Group }\end{array}$} & \multicolumn{3}{|c|}{$\begin{array}{l}\text { Importance of the } \\
\text { SWOT Group }\end{array}$} & \multirow{2}{*}{$\begin{array}{l}\text { SWOT } \\
\text { Factors }\end{array}$} & \multicolumn{3}{|c|}{$\begin{array}{l}\text { Importance of Factors } \\
\text { within Group }\end{array}$} & \multicolumn{3}{|c|}{$\begin{array}{c}\text { General Importance of } \\
\text { Factors }\end{array}$} \\
\hline & $\begin{array}{c}\text { Loca } \\
1 \\
\text { Peop } \\
\text { le }\end{array}$ & $\begin{array}{c}\text { Expe } \\
\text { rts }\end{array}$ & $\begin{array}{c}\text { Local } \\
\text { Admi } \\
\text { nistra } \\
\text { tors }\end{array}$ & & $\begin{array}{c}\text { Loca } \\
\text { l } \\
\text { Peo } \\
\text { ple }\end{array}$ & $\begin{array}{c}\text { Expe } \\
\text { rts }\end{array}$ & $\begin{array}{c}\text { Local } \\
\text { Admi } \\
\text { nistr } \\
\text { ators }\end{array}$ & $\begin{array}{c}\text { Loca } \\
1 \\
\text { Peo } \\
\text { ple }\end{array}$ & $\begin{array}{l}\text { Expe } \\
\text { rts }\end{array}$ & $\begin{array}{c}\text { Local } \\
\text { Admin } \\
\text { istrato } \\
\text { rs }\end{array}$ \\
\hline \multirow{8}{*}{ 柒 } & & & & ES1 & $\begin{array}{l}0.13 \\
3\end{array}$ & 0.139 & 0.102 & $\begin{array}{l}0.03 \\
3\end{array}$ & 0.035 & 0.025 \\
\hline & & & & ES2 & $\begin{array}{l}0.12 \\
1\end{array}$ & 0.154 & 0.153 & $\begin{array}{l}0.03 \\
0\end{array}$ & 0.039 & 0.038 \\
\hline & & & & ES3 & $\begin{array}{l}0.14 \\
5\end{array}$ & $\begin{array}{l}0.16 \\
6\end{array}$ & 0.159 & $\begin{array}{l}0.03 \\
7\end{array}$ & 0.042 & 0.040 \\
\hline & & & & ES4 & $\begin{array}{l}0.14 \\
3\end{array}$ & 0.119 & 0.159 & $\begin{array}{l}0.03 \\
6\end{array}$ & 0.030 & 0.040 \\
\hline & $\begin{array}{c}0.25 \\
2\end{array}$ & 0.252 & 0.250 & ES5 & $\begin{array}{l}0.11 \\
3\end{array}$ & 0.109 & 0.064 & $\begin{array}{l}0.02 \\
9\end{array}$ & 0.027 & 0.016 \\
\hline & & & & ES6 & $\begin{array}{l}0.09 \\
5\end{array}$ & 0.068 & 0.070 & $\begin{array}{l}0.02 \\
4\end{array}$ & 0.017 & 0.018 \\
\hline & & & & ES7 & $\begin{array}{l}0.14 \\
2\end{array}$ & 0.144 & 0.127 & $\begin{array}{l}0.03 \\
6\end{array}$ & 0.036 & 0.032 \\
\hline & & & & ES8 & $\begin{array}{l}0.10 \\
7\end{array}$ & 0.100 & 0.166 & $\begin{array}{l}0.02 \\
7\end{array}$ & 0.025 & 0.041 \\
\hline \multirow{5}{*}{3} & & & & EW1 & $\begin{array}{l}0.14 \\
4\end{array}$ & 0.129 & 0.166 & $\begin{array}{l}0.04 \\
3\end{array}$ & 0.037 & 0.033 \\
\hline & & & & EW2 & 0.08 & 0.098 & 0.066 & 0.02 & 0.028 & 0.013 \\
\hline & $\begin{array}{c}0.29 \\
5\end{array}$ & 0.286 & 0.200 & EW3 & $\begin{array}{l}1 \\
0.08 \\
9\end{array}$ & 0.097 & 0.053 & $\begin{array}{l}4 \\
0.02 \\
6\end{array}$ & 0.028 & 0.011 \\
\hline & & & & EW4 & $\begin{array}{l}0.12 \\
1\end{array}$ & 0.126 & 0.159 & $\begin{array}{l}0.03 \\
6\end{array}$ & 0.036 & 0.032 \\
\hline & & & & EW5 & $\begin{array}{l}0.12 \\
0\end{array}$ & 0.119 & 0.132 & $\begin{array}{l}0.03 \\
5\end{array}$ & 0.034 & 0.026 \\
\hline
\end{tabular}




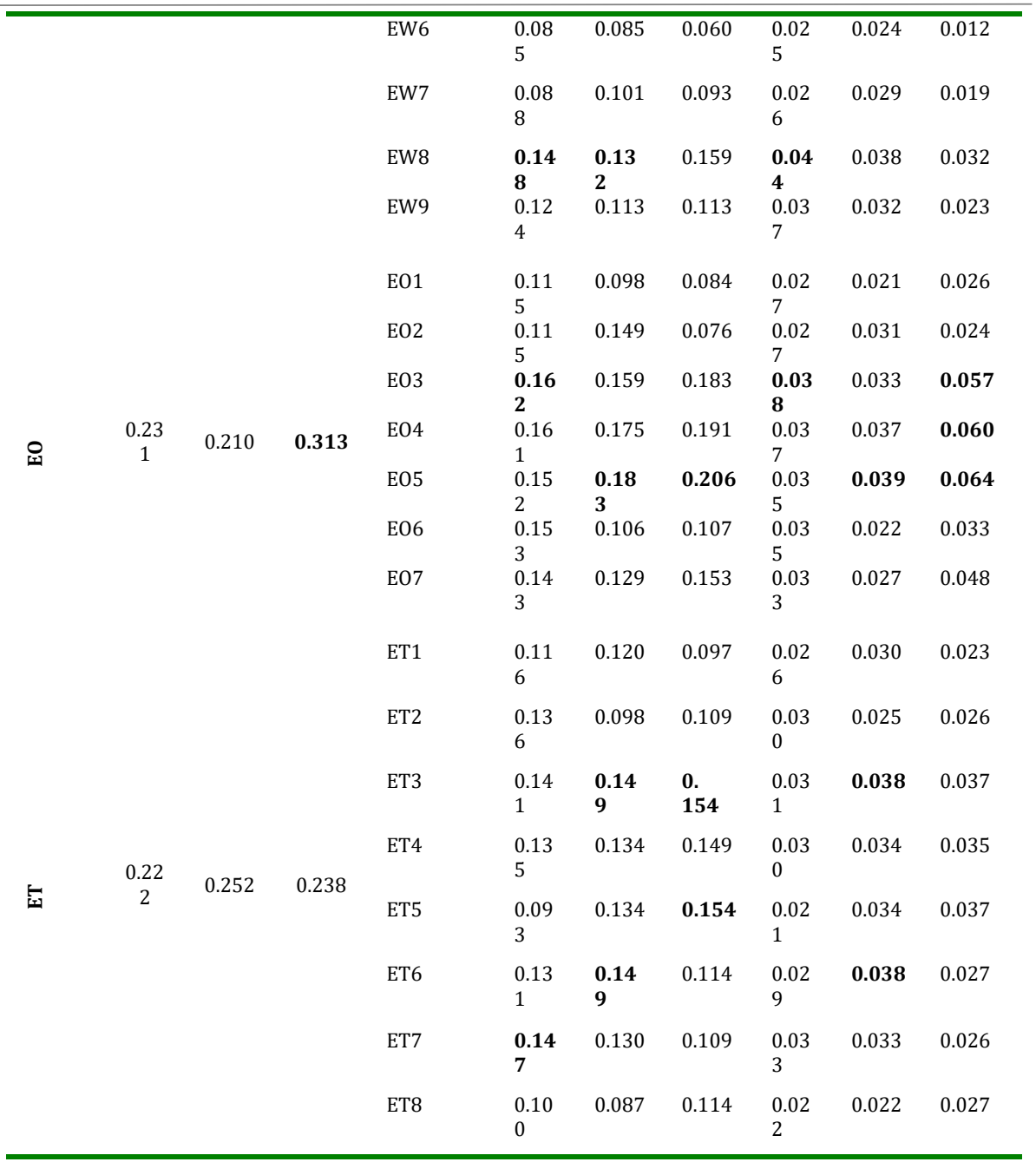

Local people rated the group of "economic weaknesses" as the most important group with a priority value of 0.295 (29.5\%) and "economic threats" as the least important group with a value of $0.222(22.2 \%)$. When we look at the significance of economic SWOT factors within the group, it can be observed that ES3 from the group of economic strengths $(14.5 \%)$, EW8 from the group of economic weaknesses (14.8\%), EO3 from the group of economic opportunities (16.2), and lastly ET7 from the group of economic threats (14.7) occupy the first places in terms of significance within their respective groups (Figure 3). When the general weights of the factors are analyzed, it is seen that EW8 (4.4\%), EW1 (4.3\%) from the economic weakness group and EO3 (3.8\%) from the economic opportunities group share the first three places. 
Figure 3. Evaluation of the importance levels of economic SWOT groups within the factor by the local people (\%).
Assessment of The Rural Economic Structure of Güdül Town (Ankara) by Quantified Swot Analysis

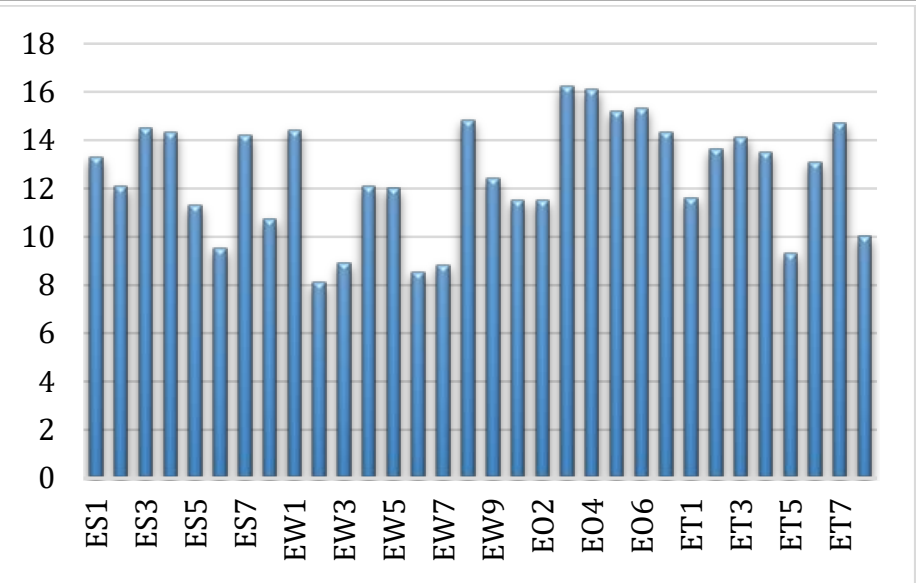

Experts identified the group of economic weaknesses as the most important group with a priority value of 0.286 (28.6\%) and economic opportunities as the least important one with a priority value of 0.216 (21\%). As for the importance of economic SWOT factors within groups, we can observe that ES3 (16.6\%) in economic strengths, EW8 (13.2\%) from economic weaknesses, E05 (18.3\%) from economic opportunities, and ET3 (14.9\%) and ET6 (14.9\%) from economic threats groups occupy the first place in terms of significance within their respective groups (Figure 5). In terms of the general weights of the factors, it can be seen that ES3 (4.2\%); ES2 (3.9\%) and EO5 (3.9\%); and ET3 (3.8\%) and ET6 $(3.8 \%)$ share the top three places (Figure 6).

Figure 4. Evaluation of general importance levels of economic SWOT analysis factors by local people (\%) within the factor by the local people (\%).

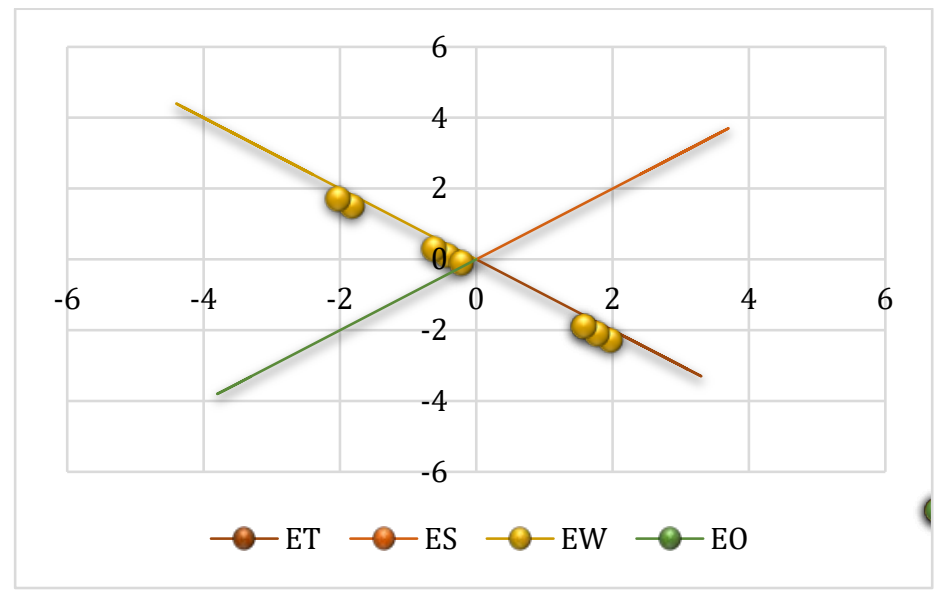




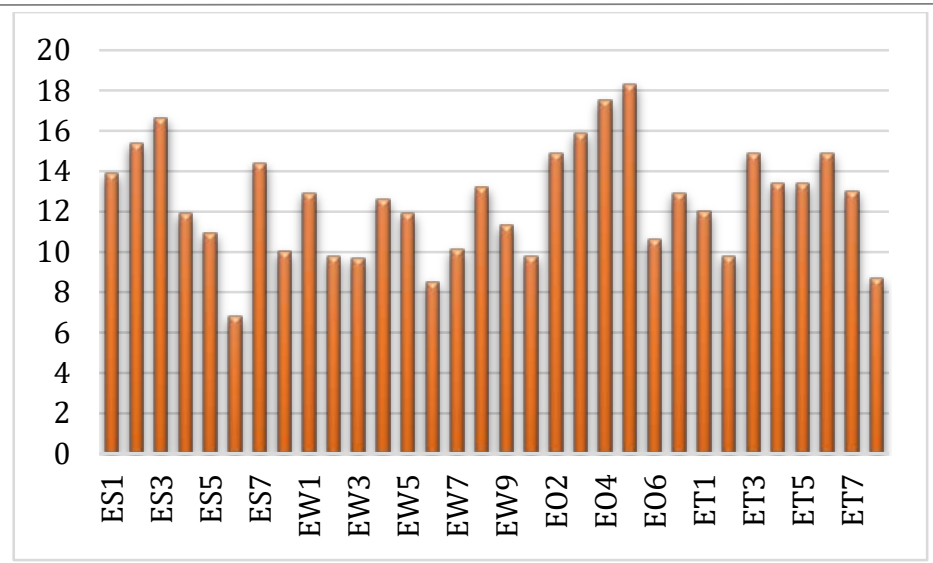

Figure 5. Evaluation of the importance levels of economic SWOT groups within the factor by experts (\%).

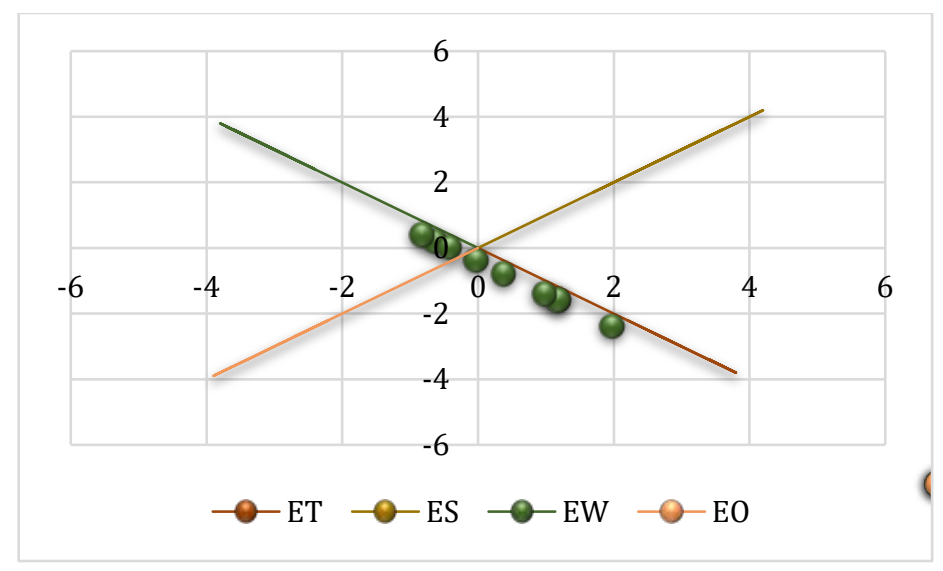

Figure 6. Evaluation of general severity degrees of economic SWOT analysis factors by experts (\%).

Lastly, local administrators rated the group of economic opportunities as the most important group with a priority value of $0.313(31.3 \%)$ and economic weaknesses as the least important group with a value of 0.200 $(20 \%)$. When we look at the significance of economic SWOT factors within the group, it can be observed that ES8 (16.6\%) from the group of economic strengths, EW1 (16.6\%) from the group of economic weaknesses, E05 (20.6\%), from the group of economic opportunities and lastly ET3 (14.7) and ET5 (15.4\%) from the group of economic threats occupy the first places in terms of significance within their respective groups (Figure 7). In terms of the general weights of the factors, E05 $(6.4 \%)$, EO4 (6\%), and EO3 (5.7\%) from the group of economic opportunities share the top three places (Figure 8). 
Assessment of The Rural Economic Structure of Güdül Town (Ankara) by Quantified Swot Analysis

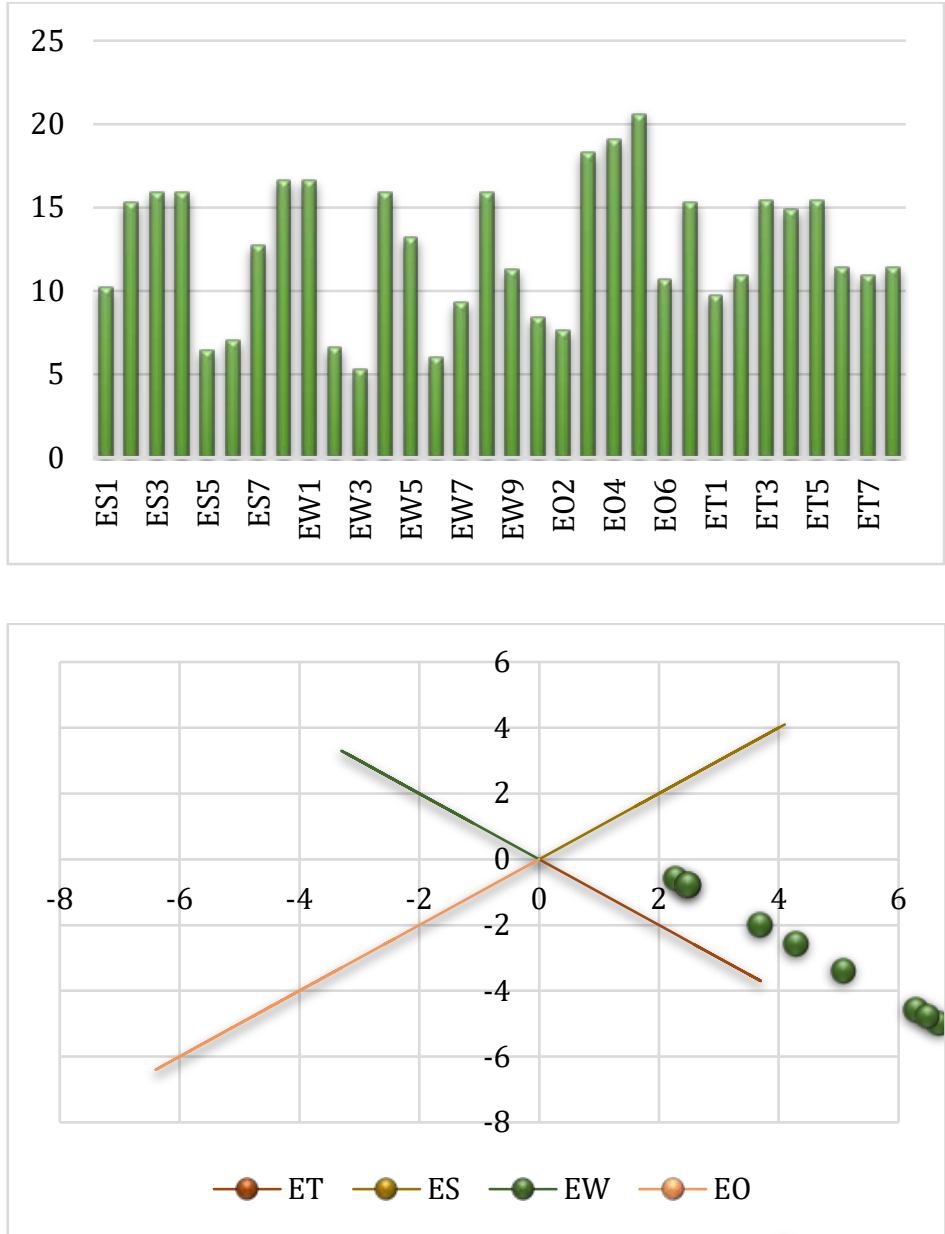

Figure 7. Evaluation of the importance levels of economic SWOT groups within the factor by local administrators (\%).

Figure 8. Evaluation of general importance degrees of economic SWOT analysis factors by local administrators (\%).

Figure 9. Evaluation of the importance levels of economic SWOT groups within the factor according to stakeholder groups (\%).
When the priority levels of economic SWOT groups within factors are assessed by stakeholders, it transpired that local administrators attached the highest and the local people the lowest significance to economic SWOT groups (Figure 9).

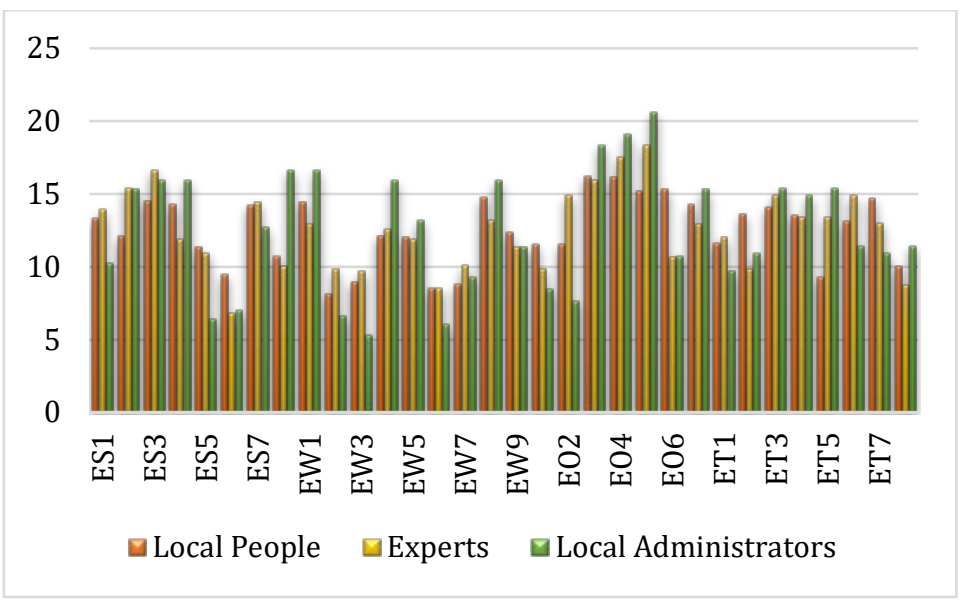

The importance given by stakeholders to SWOT groups has a foundational impact in the establishment of rural economic development plans of Güdül. When the priority levels that are identified by taking the 
geometric mean of the economic SWOT analysis group weights are explored (Table 6 and Table 7):

Table 6. Comparison of significance levels of the economic SWOT group

\begin{tabular}{lcccc}
\hline SWOT Group & Local People & Experts & $\begin{array}{c}\text { Local } \\
\text { Administrators }\end{array}$ & $\begin{array}{c}\text { Güdül Rural } \\
\text { Economic } \\
\text { Development } \\
\text { Strategy }\end{array}$ \\
\hline & & & & \\
EGY & 0.031 & $\mathbf{0 . 0 3 1}$ & 0.031 & 0.031 \\
EZY & 0.032 & $\mathbf{0 . 0 3 1}$ & 0.022 & 0.027 \\
EF & $\mathbf{0 . 0 3 3}$ & 0.030 & $\mathbf{0 . 0 4 4}$ & $\mathbf{0 . 0 3 5}$ \\
ET & 0.027 & $\mathbf{0 . 0 3 1}$ & 0.029 & 0.028 \\
\hline
\end{tabular}

Table 7. Economic SWOT group effects of Güdül rural economic development strategy

\begin{tabular}{lccccc}
\hline SWOT & $\begin{array}{c}\text { Local } \\
\text { People }\end{array}$ & Experts & $\begin{array}{c}\text { Local } \\
\text { Administrators }\end{array}$ & $\begin{array}{c}\text { Güdül Rural } \\
\text { Development Strategy }\end{array}$ \\
\hline Economic & 0.030 & 0.030 & 0.030 & $\mathbf{0 . 0 3 0}$ & $\mathbf{1 1 . 5 8 \%}$ \\
\hline
\end{tabular}

Economic SWOT groups were equally valued by the three stakeholder groups. Within group, economic opportunities carry the highest weight identified by the local people. On the one hand, experts equally valued economic strengths, weaknesses, and threats and rated almost all the economic SWOT groups equally. On the other hand, economic opportunities carry the highest weight identified by the local administrators, which is higher than the rating of that of local people (Table 6). The economic SWOT group with the highest priority value in Güdül's rural development strategy is economic opportunities with 0.035 (3.5\%) (Table 7). In the general evaluation conducted by taking the geometric mean of economic SWOT groups, economic group was identified as the fourth most valued SWOT group with a score of $11.58 \%$. As for the general evaluation conducted by taking the geometric mean of the assessment of economic SWOT groups, economic group ranks as the fourth most valued SWOT group with a rating of $11.58 \%$ (Figure 10).

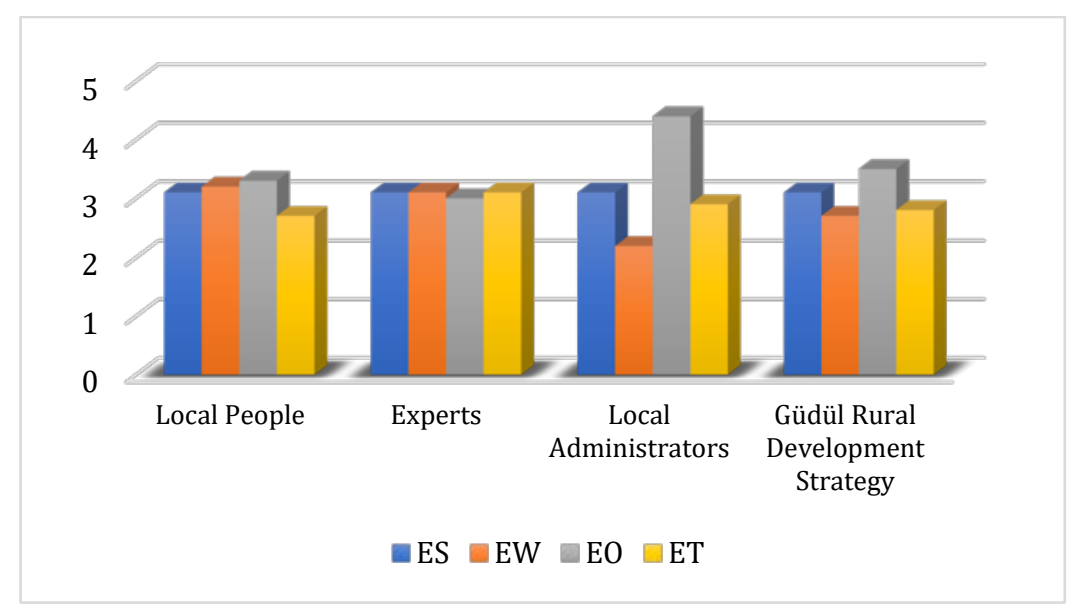

Figure 10. Economic SWOT group effects of Güdül rural economic development strategy. 
Assessment of The Rural Economic Structure of Güdül Town (Ankara) by Quantified Swot Analysis

Economic strategic objectives have been identified by using the TOWS matrix based on the logical coherence of Güdül's SWOT factors. TOWS matrix defines four conceptually-different strategic groups with a view to producing alternative strategies. These groups are,

-Strengths - Opportunities (SO): Strategies to reinforce the strengths by using opportunities,

-Strengths - Threats (ST): Strategies to reduce / eliminate the threats by using strengths,

-Weaknesses - Opportunities (WO): Strategies to turn weaknesses into opportunities

-Weaknesses - Threats (WT): Strategies to alleviate the weaknesses and threats (Seebohm, 2014).

The TOWS Matrix prepared for Güdül's strategic rural development model includes successful defensive strategies to lessen the effects of weaknesses (W) and to minimize the effects of threats (T). Also included in this matrix are Strategic Goals (SG) and sub-strategies under four groups, namely physical, social, economic, and administrative. These groups encapsulate the potentials arising from strengths (S) and opportunities (0) (Table 8). The SWOT factors primarily taken into account by the suggested Strategic Goals are presented in the chart below:

Table 8. Economic SWOT group effects of Güdül rural economic development strategy

\begin{tabular}{|c|c|c|}
\hline $\begin{array}{c}\text { Economic } \\
\text { TOWS } \\
\text { Matrix }\end{array}$ & Economic Strengths (ES) & Economic Weaknesses (EW) \\
\hline & ESO Strategies & EWO Strategies \\
\hline 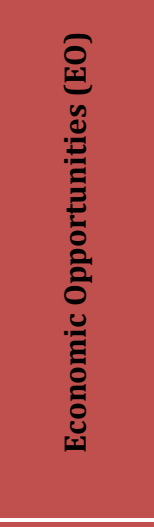 & $\begin{array}{l}\text { ESG 1: Improving Agricultural } \\
\text { Economy and Increasing } \\
\text { Employment Opportunities } \\
\text { (ES1, ES4, ES7, EO1, E02, EO3, } \\
\text { EO4, EO6) }\end{array}$ & $\begin{array}{c}\text { ESG 2: Developing Competitiveness } \\
\text { and Marketing Infrastructure } \\
\text { ESG 3: Supporting Food Security } \\
\text { Efforts } \\
\text { ESG 4: Developing Rural Industry } \\
\text { Infrastructure } \\
\text { ESG 5: Assuring the Diversity of } \\
\text { Local Products } \\
\text { ESG 6: Reinforcing the } \\
\text { Cooperativization Infrastructure } \\
\text { (EW1, EW2, EW3, EW4, EW5, EW6, } \\
\text { EW7, EW8, EW9, E01, E02, E03, } \\
\text { E04, E05, E06, E07) }\end{array}$ \\
\hline & EST Strategies & EWT Strategies \\
\hline 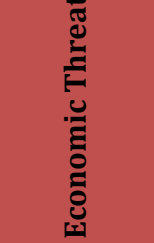 & $\begin{array}{l}\text { ESG 7: Bolstering the Rural } \\
\text { Tourism Infrastructure } \\
\text { ESG 8: Increasing the Potential } \\
\text { for Added Value and Branding } \\
\text { (OS2, OS3, OS9, OT1, OT3, OT4) }\end{array}$ & $\begin{array}{l}\text { ESG 9: Increasing the Capacity of } \\
\text { Animal Husbandry } \\
\text { ESG 10: Increasing Institutional } \\
\text { Capacity } \\
\text { (OW1, OW7, OW9, OT1, OT4) }\end{array}$ \\
\hline
\end{tabular}




\section{Economic Strategic Goals (ESG)}

ESG 1: Improving Agricultural Economy and Increasing Employment Opportunities;

(ESG 1.1) Making the agriculture and food sectors more competitive,

(ESG 1.2) Promoting small and medium-scale family businesses in order to ensure the sustainability of vineyards and fruit orchards in town.

(ESG 1.3) Promoting modern agriculture methods such as urban agriculture and hobby farms in order to protect the qualities of the vineyards and fruit orchards in town.

(ESG 1.4) Establishing farmer's markets for the foundation of a local market.

ESG 2: Developing Competitiveness and Marketing Infrastructure;

(ESG 2.1) Raising awareness among producers regarding the cultivation of marketable products with high relative profit rates. (ESG 2.2) Launching planning efforts regarding the variety and minimum quantity of products and also standard production with the purpose of increasing the marketability of agricultural products.

(ESG 2.3) Planning and implementing support mechanisms regarding the products that are intended to be cultivated in the region.

(ESG 2.4) Establishing support mechanisms for agricultural production associations and farmers to expand the international sales volume.

(ESG 2.5) Assisting with the projects that aim reinforcing the region's infrastructure of supply channels and distribution of products.

(ESG 2.6) Establishing buying centers and product stock markets for the sale of products with added value.

(ESG 2.7) Upgrading the town's website and using it for communication and marketing and promotion local products.

ESG 3: Supporting Food Security Efforts;

(ESG 3.1) Establishing control and inspection mechanisms for food security.

(ESG 3.2) Working towards raising awareness about food security in producers and consumers.

\section{ESG 4: Developing Rural Industry Infrastructure;}

(ESG 4.1) Founding an Agriculture-based Organized Industrial Zone.

(ESG 4.2) Increasing the potential for animal husbandry and supporting the farms founded away from residential areas in order to avoid disturbing the local people with the foul smell coming from barns. 
Assessment of The Rural Economic Structure of Güdül Town (Ankara) by Quantified Swot Analysis

(ESG 4.3) Developing the necessary industrial infrastructure for the production of angora wool which is native to Ankara and makes a significant contribution to local and regional economy.

(ESG 4.4) Improving the fodder and hay production facilities to be used in animal husbandry.

ESG 5: Assuring the Diversity of Local Products;

(ESG 5.1) Improving the seed policies in order to assure the sustainability of the diversity of local products.

(ESG 5.2) Establishing seed-producing cooperatives to make local seeds more accessible and to promote the production of seeds.

(ESG 5.3) Founding seed banks to collect and preserve organic and durable seeds.

(ESG 5.4) Popularizing the production of saplings and seedlings.

ESG 6: Reinforcing the Cooperativization Infrastructure;

(ESG 6.1) Expanding the opportunities for cooperatives to do sale both in local markets and online.

(ESG 6.2) Increasing grant opportunities for cooperatives.

\section{ESG 7: Bolstering the Rural Tourism Infrastructure;}

(ESG 7.1) Integrating the natural resources located in rural residential areas and the areas with high brand value (Kirmir Stream, Sorgun Pond, İnönü Caves etc.) into the tourism activities in the region within the framework of rural tourism projects.

(ESG 7.2) Using the advantages of Ankara's position as the center of Turkey's and the Middle East 's health sectors in order to integrate Güdül's geothermal tourism potential (e.g., Çağa region) into health tourism.

(ESG 7.3) Making up for the shortage in accommodation facilities and making improvements in this sector due to the fact that tourism sector does not make a significant contribution to local economy.

(ESG 7.4) Promoting farm tourism activities especially in vineyard houses, where one can spend weekends, and rural residential places.

(ESG 7.5) Presenting the town's agricultural production and the diversity in products in short educational courses delivered to domestic and international tourists interested in agritourism, and integrating this project with the tourism infrastructure.

(ESG 7.6) Making the grape production in the town's vineyards compatible with wine tourism and creating wine-tasting tours for domestic and international tourists.

(ESG 7.7) Developing gastronomy tourism in rural residential areas.

(ESG 7.8) Generating creative tourism ideas to develop knifemaking industry. 


\section{ESG 8: Increasing the Potential for Added Value and Branding;}

(ESG 8.1) Supporting the production of roasted chickpeas, which carry the potential for branding, and creating sale mechanisms.

(ESG 8.2) Improving the promotion mechanisms for angora wool, which carries the potential for branding and contributing to local and regional economy.

(ESG 8.3) Utilizing the potentials of products that could provide added value to town's economy.

\section{ESG 9: Increasing the Capacity of Animal Husbandry;}

(ESG 9.1) Urging the production of organic fodder crops in pastures that carry the potential for organic production so as to eliminate the deficit in fodder availability observed in organic animal husbandry.

(ESG 9.2) Founding of grazing administration associations.

(ESG 9.3) Promoting the amelioration of pastures that are located in areas facing the pressure of urban development.

(ESG 9.4) Forming support mechanisms by increasing the numbers of cattle, small cattle, and poultry.

(ESG 9.5) Designing incentive mechanisms for the cultivation of angora goat.

(ESG 9.6) Raising awareness among local people regarding the state support, such as bee and hive support, that aims at increasing the potential of apiculture.

(ESG 9.7) Taking precautions against the damage inflicted on fisheries and the pollution caused by the fishing activities in Kirmir Stream.

\section{ESG 10: Increasing Institutional Capacity;}

(ESG 10.1) Leading research and development efforts in order to increase institutional capacity with the purpose of enhancing the capacity of branding and international trade.

\section{DISCUSSION AND RESULTS}

There are several factors that enhance the chances of success in rural development. Among these are: clearly demarcating the boundaries of the changing texture of rural areas and interaction areas; determining rural development policies and strategies that could help the utilization of the potential of rural areas effectively and productively and minimization of the negative factors that impede or slow down the improvement; identifying the stakeholders who directly affect and are affected by the rural development process; ensuring the active participation of disadvantaged groups in the process; identifying the needs and demands of the said stakeholders through participatory approaches in order to increase the livability and sustainability of rural areas; developing governance and participation mechanisms towards the improvement of rural development and organizational capacities; conducting the analyses of the current situation to determine the strengths, weaknesses, threats, and opportunities regarding the rural 
area and quantifying the results; designating a transparent, fair, and sustainable rural development vision within the framework delineated by the stakeholders in the rural area; and creating strategies within the scope of this vision and preparing action plans. The method used in this study is an important step in overcoming the difficulties in determining the policies of the district and determining the priority values of these policies in the process of decision making for the quality life desire of the locals that affect and are affected by the rural area.

The results of the study contribute to planning efforts not only in theoretical perspectives but also in the implementation, policydevelopment, and auditing stages. It is believed that the results will provide the experts and authorities with significant data regarding the planning efforts in the strategic rural development, and the resulting model proposal can be applied to other rural areas in Turkey that are trying to maintain their rural characteristics at the periphery of metropolitan municipalities.

The town of Güdül possesses high potential to become one of the tourist attraction areas due to its proximity to a metropolitan city, which is also Turkey's capital, when necessary steps are taken in the way of rural development projects. The leading factors impeding rural development in town are shortages in employment areas and labor force. The respective needs for a population to preserve the rural texture, for the existence of agricultural production to bring added value to economy, and for employment areas to uphold rural economy are among the most important obstacles in front of Güdül's rural development.

The current situation of Güdül's rural development, its potentials, and non-negligible weaknesses have been identified through an economic SWOT analysis of the area. During the process of designing a rural economic development strategy for the town of Güdül, the current situation and the general framework were delineated by a SWOT analysis, a quantified method. Secondly, the resulting economic SWOT group and the priority values of the SWOT factors subsumed under this group were identified and prioritized by using the AHP method.

The most important problem of agricultural production in Güdül is considered to be the inadequacy of irrigation areas and water supply. Especially after the enactment of the law that turned villages into neighborhoods, charging for water use started, which increased the costs. The downward tendency in the number of animals and animal production picked up speed with the changing legal processes. Moving the barns away from residential areas in urban neighborhoods on account of foul smell significantly increased costs. Also, because the absence of Organized Industrial Zones based on agriculture and animal husbandry decreases the revenue that could be generated from these sectors, farming livelihood is no longer considered as an option. Animal and agricultural products are sold under market value due to the deficiencies in marketing infrastructure, and lack of production and sales 
organizations for products that could bring added-value restrict the overall production.

Within the framework of this vision, a TOWS matrix that is based on the integration of SWOT factors and also physical, social, economic, and administrative strategic objectives for Güdül were generated in consideration of the strategies developed for Güdül's rural development. Then, in order to implement the strategic objectives and to complete Güdül's rural development process, action plans were created to identify the institutions responsible for the strategies.

A number of economic strategies have been developed in order for the rural economy to provide added value. These include:

- Improving agricultural economy and increasing employment opportunities,

- $\quad$ Developing the infrastructure for competitiveness and marketing

- Supporting food security efforts,

- Developing the rural industrial infrastructure,

- Assuring diversity in local products,

- Reinforcing the cooperativization infrastructure,

- $\quad$ Reinforcing the rural tourism infrastructure

- Increasing the potential for added-value and branding,

- Enhancing the capacity for animal husbandry,

- Increasing institutional capacity.

When we examine the studies planned in the scope of this research and the recommendations for the experts, researchers, and practitioners who are interested in this subject, we see that identification of in-group weights and the general weights for the quantification of the SWOT factors with the AHP method that involves a transparent participation process could ensure prioritization of needs and expectations, in addition to providing the groundwork for specifying a rural development vision and a rural development plan that is feasible and sustainable in the course of AHP. Additionally, this approach promotes discovering actual problems and rational approaches to find out solutions. This advantage, in turn, satisfies expectations and leads to a decrease in emigration rates by increasing the life quality and happiness levels of stakeholders, who are affected by the process of rural development. When rural development studies follow priority plans, they contribute to sustaining local identities and achieving the targeted success rates.

The results of this study show that combining SWOT analysis and AHP method is an effective and useful way to identify the economic strategies of rural development. On the one hand, SWOT analysis revealed the economic strengths and weaknesses Güdül's economy as well as the threats and opportunities it can encounter. On the other, AHP method was utilized in the identification of priorities while developing strategies regarding the SWOT factors.

Thus, SWOT analysis, a qualitative method, has acquired a quantitative aspect with the help of AHP and factors with the highest scores in the development of strategies were prioritized and weighted. In this respect, 
Assessment of The Rural Economic Structure of Güdül Town (Ankara) by Quantified Swot Analysis

this study could provide a model for similar studies that focus on rural development from various perspectives (socio-cultural, physical environment etc.)

Also, it is our expectation that consideration of the strategies put forward in this study by local administrators and decision-makers would significantly contribute to the proper utilization of the economic rural development potential of Güdül.

\section{ACKNOWLEDGEMENTS/NOTES}

This article is an excerpt from Buse Şahin Dereyurt's Master Dissertation titled " The Model of Strategic Rural Development: Ankara-Güdül Case ", supervised by Asst. Prof. Dr. Elif Gündüz at Konya Technical University in 2019.

\section{CONFLICT OF INTEREST}

There was no conflict of interest.

\section{FINANCIAL DISCLOSURE}

The authors declared that this study has received no financial support.

\section{ETHICS COMMITTEE APPROVAL}

Ethics committee approval was not required for this article.

\section{LEGAL PUBLIC/PRIVATE PERMISSIONS}

In this research, the necessary permissions were obtained from the relevant participants (individuals, institutions, and organizations) during the survey and in-depth interviews.

\section{REFERENCES}

Akbulak, C. (2016). Ardahan ilinde kırsal turizm potansiyelinin sayısallaştırılmış SWOT analizi ile değerlendirilmesi. doi:10.20304/husbd.86882

Aksoy, H. H., \& Elmacl, D. (2009). Örneklem seçimi ve hesaplaması Retrieved from 80.251.40.59/education.ankara.edu.tr/aksoy/eay/eay/b0506/delmaci.

doc. $\quad$ Retrieved $19 \quad$ Temmuz 2019
80.251.40.59/education.ankara.edu.tr/aksoy/eay/eay/b0506/delmaci. doc

Anonymous. (2017). Güdül district research report. Retrieved from Ankara:

Anonymous. (2019a, 17 Temmuz 2019). Gudul investigation of development aspects. Retrieved from https://www.ankaraka.org.tr/tr/arama?q=g\%C3\%BCd\%C3\%BCl

Anonymous. (2019b). Gudul technical infrastructure. Retrieved from https://gudul.bel.tr/

Baycan Levent, T., Gülümser, A. A., \& Nıjkamp, P. (2010). Türkiye’nin kırsal yapısı: AB düzeyinde bir karşılaştırma. İtü Dergisi/a, 9(2), 133-144. 
Cengiz, T., \& Çelem, H. (2005). Hızlı kırsal değerlendirme yöntemi: Alpağut köyü örneği (Seben, Bolu). Kafkas Üniversitesi Artvin Orman Fakültesi Dergisi, 6(1-2), 161-170.

Champion, T., \& Hugo, G. (2004). New forms of urbanization: beyond the urbanrural dichotomy. Aldershot: Ashgate.

Çelik, N., \& Murat, G. (2008). Sayısallaştırılmış SWOT analizi ile Bartın ilinin ekonomik yapısını değerlendirme Paper presented at the 2. Ulusal İktisat Kongresi, İzmir.

Geray, C. (2011). Dünden bugüne kırsal gelişme politikaları. Ankara.

Gülçubuk, B. (2015). Dünya'da Avrupa Birliği'nde ve Türkiye'de kırsal kalkınma yaklaşımlarında değişimler Retrieved from https://acikders.ankara.edu.tr/mod/resource/view.php?id=8616 Retrieved 12 Haziran 2019, from Ankara Üniversitesi Ziraat Fakültesi Tarım Ekonomisi Bölümü https://acikders.ankara.edu.tr/mod /resource/view.php?id=8616

Ilbery, B. W. (1998). The geography of rural change. London.

Kangas, J., Kurtilla, M., \& Kajanus, M. (2003). Evaluating the management strategies of a forestland estate - the S-O-S approach. Journal of Environmental Management, 69, 349-358.

Kaplan, H. (2007). Kentsel sit alanı bulunan Anadolu kasabalarında turizm seçeneği olarak eko turizm - Güdül örneği. (Uzmanlık Tezi). Gazi Üniversitesi, Ankara. Retrieved from https://www.rese archgate.net/publication/302460439_KENTSEL_SIT_ALANI_BULUNAN_ ANADOLU_KASABALARINDA_TURIZM_SECENEGI_OLARAK_EKO_TURIZ M_-_GUDUL_ORNEGI_-

_ECO_TOURISM_AS_A_TOURIST_DEVELOPMENT_ALTENATIVE_FOR_AN ATOLIAN_SMALL_TOWNS_WITH_A_CONSERVATION_AREA-_G

Kurtilla, M., Pesonen, M., Kangas, J., \& Kajanus, M. (2000). Utilizing the analytic hierarchy process AHP in SWOT analysis - a hybrid method and its application to a forest-certification case. Forest Policy and Economics, 1, 41-52.

Leskinen Leena, A., Leskinen, P., Kurtilla, M., Kangas, J., \& Kajanus, M. (2006). Adapting modern strategic decision support tools in the parcipatory strategy process - a case study of a forest research station. Forest Policy and Economics, 8, 267-278.

Masozera, M. K., Alavalapatı, J. R. R., Jacobson, S. K., \& Shresta, R. K. (2004). Assessing the suitability of community-based management for the Nyungwe Forest Reserve. Forest Policy and Economics.

Moseley, M. J. (2012). Rural development principles and practice. doi:http://dx.doi.org/10.4135/9781446216439

Nijkamp, P., Baycan, T., \& Gulumser Akgun, A. (2006). Turkey's Rurality: A Comparative Analysis At the EU Level. Retrieved from https://www.researchgate.net/publication/23732183_Turkey's_Ruralit y_A_Comparative_Analysis_At_the_EU_Level

Özkan, E. (2007). Türkiye'de kırsal kalkınma politikaları ve kırsal turizm. (Yüksek Lisans Tezi). Ankara Üniversitesi Sosyal Bilimler Enstitüsü Kamu Yönetimi ve Siyaset Bilimi Anabilim Dalı, Ankara. Retrieved from 
Assessment of The Rural Economic Structure of Güdül Town (Ankara) by Quantified Swot Analysis

http://www.hazarsam.com/up/doc/191/turkiye-de-kirsal-kalkinmapolitikalari-ve-kirsal-turizm.pdf

Rovai, M., \& Andreoli, M. (2018). Integrating AHP and GIS Techniques for Rural Landscape and Agricultural Activities Planning. In Multicriteria Analysis in Agriculture.

Saaty, T. L. (2008). Relative measurement and its generalization in decision making why pairwise comparisons are central in mathematics for the measurement of Intangible factors the analytic hierarchy/network process. Paper presented at the Review of the Royal Spanish Academy of Sciences Series a Mathematics (RACSAM).

Saaty, T. L., \& Vargas, L. G. (2001). Models, methods, concepts \& applications of the analytic hierarchy process. Boston, USA: Kluwer's Academic Publishers.

Seebohm, L. (2014). Collaborative tools for strategic line planning. Retrieved from https://concurrentstrategies.com/wpcontent/uploads/2015/01/ConcurrentStrategies_SWOT-TOWS_12-

14.pdf. Retrieved 22.10.2019, from Concurrent Srategies https://concurrentstrategies.com/wp-content/uploads/2015/01/Co ncurrentStrategies_SWOT-TOWS_12-14.pdf

Şahin, B., \& Gündüz, E. (2018). A comprehensive SWOT analysis for strategic rural development-Gudul case. Paper presented at the III. Ines Education and Social Science Congress, Alanya, Antalya. Sosyal ve Beșeri Bilimler Araştırmaları retrieved from

Tekeli, İ. (2016). Dünya'da ve Türkiye'de kent-kır karşıtlı̆ğ yok olurken yerleşmeler için temsil sorunları ve strateji önerileri (Vol. 2). Ankara: İdealkent Yayınları.

Yılmaz, A., \& Zorlu, K. (2018). SWOT-AHS analizi kullanılarak Sinop'ta sürdürülebilir turizm stratejilerinin önceliklendirilmesi. Uluslararası Sosyal Araştırmalar Dergisi, 11.

\section{Resume}

Buse Şahin Dereyurt is currently continuing her PhD study at Gazi University Faculty of Architecture, Department of City and Regional Planning, Ankara, Turkey. She completed her masters' degree in the Graduate Program at Konya Technical University in 2019.

Elif Gündüz, Asst. Prof. Dr. Konya Technical University, Faculty of Architecture and Design, Department of City and Regional Planning, Konya. 